\title{
Prevalence and Clinical Symptoms of Human Parain- fluenza and Influenza Infections in Patients Admitted to Mazandaran Province Health Centers in 2019
}

\author{
Zeinab Daneshyar ${ }^{1,2}$ (D), Hamid Reza Goli ${ }^{1,2}$ (D), Bahman Mirzaei $^{3}$ (D), Mehdi Rabie Rudsari ${ }^{4}$ (D), Mohammad Reza Haghshenas ${ }^{1,2^{*}}$ (D)
}

1. Molecular and Cell Biology Research Centre, School of Medicine, Mazandaran University of Medical Sciences, Sari, Iran

2. Department of Medical Microbiology, School of Medicine, Mazandaran University of Medical Sciences, Sari, Iran.

3. Department of Medical Microbiology and Virology, School of Medicine, Zanjan University of Medical Sciences, Zanjan, Iran

4. HIV Laboratory, Mazandaran University of Medical Sciences, Sari, Iran.

$\begin{gathered}\text { Use your device to scan } \\ \text { and read the article online }\end{gathered}$
mattion Daneshyar Z, Goli HR, Mirzaei B, Rabie Rudsari M, Haghshenas M. Prevalence and Clinical Symptoms of Hu-
Molecular Medicine. 2019; 7(3):29-38. https://doi.org/10.32598/rmm.7.3.29
dol https://doi.org/10.32598/rmm.7.3.29

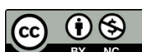

Article Type:

Research Paper

Article info:

Received: 28 May 2019

Revised: 24 Jun 2019

Accepted: 10 Jul 2019

Keywords:

Influenza virus, Human parainfluenza virus, RT-polymerase chain reaction, Real-time polymerase chain reaction

\begin{abstract}
A B S T R A C T
Background: The human parainfluenza and influenza viruses are common causes of respiratory infections in humans. The main goal of this study was to investigate the prevalence of these viruses in health centers of Mazandaran Province, Iran, and comparing their clinical manifestations.

Materials and Methods: The sample collection was done using Dacron swabs from the oropharynx of the patients, and the specimens were transferred to the laboratory by Hanks medium. The Viral genomes were isolated by the extraction kits. Then, the reverse-transcription polymerase chain reaction and real-time polymerase chain reaction methods were used for the detection of influenza and parainfluenza viruses' prevalence in the specimens, respectively.

Results: Out of 100 samples, 5 specimens (5\%) were positive for human parainfluenza, and 24 samples $(24 \%)$ were positive for the influenza virus. Among all patients, $50(50 \%)$ were female. No human parainfluenza positive patients had croup. While no significant correlation was detected between personality characteristics (sex and age) and the infection with parainfluenza viruses, there was a significant relationship between sex and the detection of influenza virus $(\mathrm{P}<0.05)$. Moreover, there was a significant relationship between some symptoms like pain and fever with the presence of the influenza virus and the symptoms such as fever and runny nose with the positive results for parainfluenza in the clinical samples $(\mathrm{P}<0.05)$.

Conclusion: The results of the study revealed the high prevalence of influenza disease in this region of Iran that calls for taking an appropriate plan for the prevention and control using diagnostic tests like polymerase chain reaction.
\end{abstract}

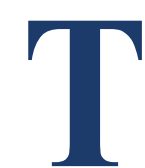

\section{Introduction}

he parainfluenza virus is a member of the

Paramyxoviridae family, which is divided into 4 serotypes (species) based on the genetic and antigenic properties: Human parainfluenza virus type 1 (HPIV1), HPIV2, HPIV3, and HPIV4 [1]. Among them, HPIV1 and HPIV3 are the members of Respiroviruses,

* Corresponding Author:

Mohammad Reza Haghshenas, PhD.

Address: Molecular and Cell Biology Research Centre, School of Medicine, Mazandaran University of Medical Sciences, Sari, Iran

Phone: +98 (811) 33543081

E-mail: haghshenas2001@yahoo.com 
while HPIV2 and HPIV4 belong to Rubulaviruses. These viruses have RNA genome with negative sense. However, some virion particles contain a genome with positive sense [2].

Such particles are incapable of creating an infection. Human parainfluenza viruses have a lipid coat [3]. The most common disease caused by these viruses is the respiratory infection, which is more common in infants and young children, leading to $40 \%$ of Lower Respiratory Tract Infections (LRTI) and $20 \%$ of respiratory illnesses in hospitalized children. Other groups, such as elderly patients admitted to hospitals, immunocompromised adults, and bone marrow transplant recipients, are high-risk groups [4]. In a healthy host, Parainfluenza Viruses (PIV) are limited to the upper respiratory tract epithelium (nose and throat), but it can also infect the lower trachea and bronchi and causes pneumonia. These complications are most commonly observed in infection caused by PIV-3 [5-7].

The main complications caused by HPIV1, HPIV2, and HPIV3 are laryngotracheitis croup, pneumonia along with bronchiolitis, and otitis media, respectively. On the other hand, the typical symptoms observed in children are pharyngitis, retinitis, wheezing with fever, and cough [8,9]. The second major cause of the LTRIs in children after Respiratory Syncytial Virus (RSV) is the parainfluenza virus. Each year, 5 million children in the United States suffer from parainfluenza-induced LRTI, while the antibody against HPIV1 is detected in $75 \%$ of the 5-year-old children. The effect of antibody on this virus is short-lived; therefore, the recurrence of the infection is common [6].

Influenza virus is a member of the Orthomyxoviridae family with segmented (7-8 segments) negative-sense genome. The virus is enveloped and contains Hemagglutinin (HA) and Neuraminidase (NA) surface glycoproteins. Hitherto, four immunological types of influenza viruses were identified: A, B, C, and D [10, 11]. The influenza virus can be spread globally. One of the most lethal epidemics of influenza occurred in 1918, leading to the death of 40 to 50 million people [12]. The World Health Organization (WHO) estimates that $10 \%$ to $20 \%$ of the world's population is infected by the flu virus annually. Of them, 3 to 5 million people are being hospitalized and 300000 to 500000 pass away [13].

Influenza virus targets the upper respiratory tract. High-risk groups included the elderly; young children; individuals with underlying pulmonary, renal, or cardiac diseases; patients with preexisting diabetes; and persons with immunodeficiency $[14,15]$. The most prominent symptoms of influenza in the first phase are shivering, headache, and dry cough. Then, high fever, lethargy, anorexia, muscle aches, and so on are seen [16]. Symptoms are more severe in children, and high temperature can cause seizures. Sometimes, gastrointestinal symptoms such as vomiting are observed in children. Important complications of influenza included pneumonia, dysplasia, myositis, cardiac dysfunction, and encephalitis Due to the genetic recombination and mutation in the genome, new strains of the virus are created [17].

The virus easily escapes from the immune system and spreads rapidly. This feature creates concern about the prevention and control of the infection through vaccination [10]. As the respiratory infections cause a large financial burden on the health systems, and they can increase mortality rates, especially in high-risk groups [18], we decided to investigate the prevalence of influenza and parainfluenza viruses in patients with flu-like symptoms admitted to health centers in Mazandaran Province.

\section{Materials and Methods}

\section{Selection of patients and sample collection}

This study was conducted in winter, 2018, on 100 patients with flu-like symptoms admitted to health centers of Mazandaran Province, North of Iran. The symptoms of the patients at the time of admission were fever, sore throat, cough, and later on, symptoms such as muscle pain, lethargy, and shivering appeared.

The specimens were collected by a sterile Dacron swab (Maxwell, china) from the oropharynx of the patients. The patients were placed in a position with appropriate light, and the specimen was collected using a swab and by pushing the tongue down, from the posterior region of the pharynx, tonsils, and inflamed areas. The specimens were placed in a viral transport medium (Hanks) and transported under the cold condition to Influenza Laboratory affiliated to Mazandaran University of Medical Sciences and were stored at $-70^{\circ} \mathrm{C}$. Variables such as age, gender, and suspected sources of infection were collected through a questionnaire for all patients.

\section{RNA extraction}

The viral RNAs were extracted from the clinical specimens by PureLinkTM Viral RNA/DNA kit (Invitrogen, USA) according to the manufacturer's instructions. Briefly, $25 \mu \mathrm{L}$ proteinase $\mathrm{K}$ was added into a microtube 
containing $200 \mu \mathrm{L}$ sample, and then $200 \mu \mathrm{L}$ lysis buffer (Containing $5.6 \mu \mathrm{g}$ carrier RNA) was added to it, and the contents were mixed by vortex for $15 \mathrm{~s}$ and incubated for $15 \mathrm{~min}$ at $56^{\circ} \mathrm{C}$. Then, $250 \mu \mathrm{L}$ of $96 \%-100 \%$ ethanol was added into the microtube and mixed by vortex for $15 \mathrm{~s}$, and incubated for $5 \mathrm{~min}$ at room temperature. In the next step, $675 \mu \mathrm{L}$ of this product was transferred into the viral spin column tube and centrifuged for 1 minute at $12000 \mathrm{rpm}(\sim 6.800 \mathrm{~g})$.

The viral spin column filter was moved into a new sterile microtube and washed two times with $500 \mu \mathrm{L}$ of wash buffer, and centrifuged for $1 \mathrm{~min}$ at $12000 \mathrm{rpm}$, and then centrifuged for $1 \mathrm{~min}$ at high speed. Next, the viral spin column filter was moved into a new sterile 1.5 $\mathrm{mL}$ microtube and $50 \mu \mathrm{L}$ of distilled water or RNase-free water was added to the middle of the viral spin column filter and incubated at room temperature for $1 \mathrm{~min}$ and then centrifuged for $1 \mathrm{~min}$ at high speed. Finally, RNA quantification was determined using a spectrophotometer (Thermo NanoDrop, USA) and residue stored at $-70^{\circ}$ $\mathrm{C}$ until use. All samples were examined at the Influenza Laboratory affiliated to Mazandaran University of Medical Sciences.

\section{Real-time polymerase chain reaction}

The real-time Polymerase Chain Reaction (PCR) method was used to detect the influenza virus. Total RNA was extracted from samples and real-time PCR was done using the Superscript III Platinum one-step kit (Invitrogen, USA) by real-time PCR system (Bio-Rad, USA) according to the distinct protocol used specific primers and independent probes (Table 1). Primers and probes, after diluting, were stored at $-20^{\circ} \mathrm{C}$, and reaction mix preparing over ice resells were contained $12.5 \mu \mathrm{L}$ of $2 \mathrm{x}$ reaction mix, $0.5 \mu \mathrm{L}(40 \mu \mathrm{M})$ of each forward and reverse primer,
$0.5 \mu \mathrm{L}(10 \mu \mathrm{M})$ of probe, $0.5 \mu \mathrm{L}$ of SuperScript III RT/ Platinum-Taq mix, and $5.5 \mu \mathrm{L}$ of RNase/DNase-free water. Then, $5 \mu \mathrm{L}$ of the extracted RNA was added to $20 \mu \mathrm{L}$ of the prior reaction mix. Thus, the final reaction volume was $25 \mu \mathrm{L}$. The amplification into the $96-$ well real-time PCR plate was progressed at $50^{\circ} \mathrm{C}$ for $30 \mathrm{~min}, 95^{\circ} \mathrm{C}$ for $2 \mathrm{~min}$ and then for 45 cycles of $95^{\circ} \mathrm{C}$ for $15 \mathrm{~s}, 55^{\circ} \mathrm{C}$ for $30 \mathrm{~s}$ and $72^{\circ} \mathrm{C}$ for $30 \mathrm{~s}$. PCR reaction was done using a CFX96 real-time system (Bio-Rad, USA) thermal cycler. After this stage, using a computer program, the results were immediately determined in programming real-time PCR. Besides the positive test, the amount of virus was determined.

\section{Multiplex reverse-transcription polymerase chain reaction}

The multiplex reverse-transcription PCR method was used to detect the parainfluenza virus. Reverse-transcription PCR was carried out in two steps of the RT step and PCR step as follows: in the first step, cDNAs were synthesized, and the next step was amplification with specific primers (Metabion, Denmark). Three sets of oligonucleotide primers used for RT and amplification of HPIV1, HPIV2, and HPIV3 are shown in Table 2. The primers were designed visually for detecting a highly conserved area of a nucleocapsid sequence of parainfluenza types 1,2, and 3. All primer sets were designed to have similar melting temperatures (ranging from $62^{\circ} \mathrm{C}$ to $64^{\circ} \mathrm{C}$ ) and a higher $\mathrm{G}+\mathrm{C}$ content to allow for using a higher annealing temperature during amplification.

Human parainfluenza viruses 1, 2, and 3, obtained from the Influenza Laboratory at Mazandaran University of Medical Sciences, were used as positive controls and for determining the specificity of the primers. These strains

Table 1. Sequences of primers and probes used in this study

\begin{tabular}{|c|c|c|c|}
\hline Virus & Target Gene & Sequence $\left(5^{\prime} \rightarrow 3^{\prime}\right)$ & Reference \\
\hline Influenza A-Forward & Matrix protein (M) & GACCRATCCTGTCACCTCTGAC & [19] \\
\hline Influenza A-Reverse & Matrix protein (M) & AGGGCATTYTGGACAAAKCGTCTA & [19] \\
\hline Influenza A- Probe & Matrix protein (M) & $\begin{array}{c}\text { FAM- } \\
\text { TGCAGTCCTCGCTCACTGGGC ACG } \\
- \text { BHQ1 }\end{array}$ & [19] \\
\hline$A(H 3)$ Subtype- Forward & Hemagglutinin gene $(\mathrm{HA})$ & AAGCATTCCYAATGACAAACC & [19] \\
\hline$A(H 3)$ Subtype- Reverse & Hemagglutinin gene $(\mathrm{HA})$ & ATTGCRCCRAATATGCCTCTAGT & [19] \\
\hline $\mathrm{A}(\mathrm{H} 3)$ Subtype-Probe & Hemagglutinin gene $(\mathrm{HA})$ & $\begin{array}{c}\text { FAM- CAGGATCACATATGGGSCCTGTCCCAG } \\
- \text { BHQ1 }\end{array}$ & [19] \\
\hline
\end{tabular}


Table 2. Sequence of primers used for the detection of human parainfluenza viruses

\begin{tabular}{|c|c|c|c|c|}
\hline Virus & Target Gene & Sequence $\left(5^{\prime} \rightarrow 3^{\prime}\right)$ & Product Length & Reference \\
\hline \multirow[t]{2}{*}{ HPIV1-F } & nucleocapsid gene (NP) & GGCGGAGGAGCAATTATACCTG & & \\
\hline & & & $81 \mathrm{bp}$ & This study \\
\hline HPIV1-R & nucleocapsid gene (NP) & ATCTGCATCATCTGTCACACTCG & & \\
\hline \multirow[t]{2}{*}{ HPIV2-F } & nucleocapsid gene (NP) & TATGTCCAGAGGAGAGGTGCTG & & \\
\hline & & & 162 bp & This study \\
\hline HPIV2-R & nucleocapsid gene (NP) & ATGCCTGCATAAGYACACTGTAG & & \\
\hline \multirow[t]{2}{*}{ HPIV3-F } & nucleocapsid gene (NP) & ACCAGGAAACTATGYTGCAGAAC & & \\
\hline & & & $231 \mathrm{bp}$ & This study \\
\hline HPIV3-R & nucleocapsid gene (NP) & CCACTGTGTCACCGCTCAATAC & & \\
\hline
\end{tabular}

grmm

were verified by FTD respiratory pathogens 21 plus kit with the real-time method.

\section{cDNA synthesis}

Viral RNA was subjected to reverse transcription using a First Strand cDNA synthesis kit (High Capacity cDNA Reverse Transcription Kit, Applied Biosystem, Germany Cat No: 4368813) according to the manufacturer's instructions.

Polymerase chain reaction amplification and product detection

We used $10 \mu \mathrm{L}$ of cDNA prepared in the reverse transcription reaction in PCR mixture containing $10 \mathrm{mM}$ of Tris- $\mathrm{HCl}$ (pH 8.5), $50 \mathrm{mM}$ of $\mathrm{KCl}, 1.5 \mathrm{mM}$ of $\mathrm{MgCl} 2$, $200 \mathrm{mM}$ of each dATP, dCTP, dGTP, and dTTP, $0.5 \mu \mathrm{M}$ of each primer, and 1.25 U of Taq polymerase (AmpliTaq; Perkin-Elmer Cetus) in a final volume of $50 \mu \mathrm{L}$ (Table 2) for amplification by a Rotor-Gene Q Thermal Cycler (QIAGEN, USA) in 40 cycles including denaturation at $95^{\circ} \mathrm{C}$ for $30 \mathrm{~s}$, annealing at $61^{\circ} \mathrm{C}$ for $30 \mathrm{~s}$, and extension at $72^{\circ} \mathrm{C}$ for $30 \mathrm{~s}$. Next, the denaturation step was done after the first cycle for $2 \mathrm{~min}$. Afterward, the elongation was performed for $5 \mathrm{~min}$ in the last cycle. The PCR products were visualized by gel electrophoresis on $1.5 \%$ agarose containing $3 \mu \mathrm{L}$ of DNA green viewer in $0.5 \times$ TBE (Tris/Borate/EDTA) buffer under UV light.

\section{Results}

In this study, 100 oropharynx swabs were collected from patients affected by influenza (having symptoms of influenza) from December 2018 to April 2019 and

Table 3. Demographic data of infected patients with human parainfluenza and influenza viruses

\begin{tabular}{|c|c|c|c|c|c|}
\hline \multirow{2}{*}{\multicolumn{2}{|c|}{ Demographics }} & \multicolumn{4}{|c|}{ No. (\%) of Patients With Positive Results } \\
\hline & & Influenza & $\mathbf{P}$ & Parainfluenza & $\mathbf{P}$ \\
\hline \multirow{3}{*}{ Gender } & Female $(n=50)$ & $16(32)$ & \multirow{3}{*}{0.049} & $1(2)$ & \multirow{3}{*}{0.181} \\
\hline & & & & & \\
\hline & Male $(n=50)$ & $8(16)$ & & $4(8)$ & \\
\hline \multirow{11}{*}{ Age groups (Year) } & $\leq 5(n=20)$ & $1(5)$ & \multirow{11}{*}{0.144} & $2(10)$ & \multirow{11}{*}{0.798} \\
\hline & $>5-15(n=6)$ & $1(16.6)$ & & - & \\
\hline & $>15-25(n=7)$ & $1(14.2)$ & & $1(14.2)$ & \\
\hline & $>25-35(n=11)$ & $4(36.3)$ & & - & \\
\hline & $>35-45(n=13)$ & $4(30.7)$ & & $1(7.6)$ & \\
\hline & & & & & \\
\hline & $>45-55(n=4)$ & $3(75)$ & & - & \\
\hline & $>55-65(n=9)$ & $1(11.1)$ & & $1(11.1)$ & \\
\hline & $>65-75(n=6)$ & $2(33.3)$ & & - & \\
\hline & $>75-85(n=15)$ & $5(33.3)$ & & - & \\
\hline & $>85(n=9)$ & $2(22.2)$ & & - & \\
\hline
\end{tabular}


Table 4. Clinical symptoms of patients with human parainfluenza and influenza

\begin{tabular}{|c|c|c|c|c|c|c|c|c|c|c|c|}
\hline \multirow[b]{2}{*}{$\begin{array}{l}\text { Clinical Signs in } \\
\text { Patients }\end{array}$} & \multicolumn{11}{|c|}{ No. (\%) of Patients } \\
\hline & 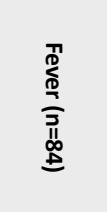 & 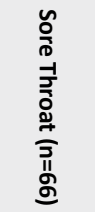 & 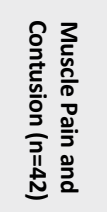 & 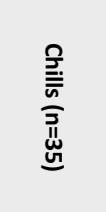 & 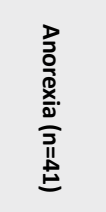 & 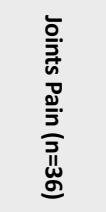 & 怘 & 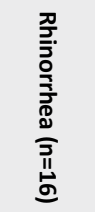 & 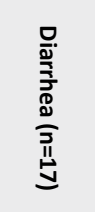 & 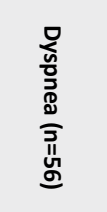 & 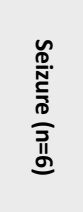 \\
\hline Influenza & $24(28.5)$ & $7(10.6)$ & $18(42.8)$ & $12(34.2)$ & $12(29.2)$ & $17(47.2)$ & $9(30)$ & $5(31.2)$ & $6(35.2)$ & $13(23.2)$ & $1(16.6)$ \\
\hline $\mathrm{P}$ & 0.021 & 0.629 & 0.0009 & 0.0009 & 0.346 & 0.0009 & 0.444 & 0.525 & 0.349 & 0.509 & 0.555 \\
\hline Parainfluenza & $5(5.9)$ & $5(7.5)$ & $4(9.5)$ & $5(14.2)$ & $4(9.7)$ & $1(2.7)$ & $3(10)$ & $3(18.7)$ & - & $4(7.1)$ & - \\
\hline P & 0.590 & 0.163 & 0.158 & 0.004 & 0.156 & 0.697 & 0.318 & 0.028 & 0.585 & 0.138 & 0.729 \\
\hline
\end{tabular}

then sent to the reference laboratory to study and confirm respiratory viruses. Totally, 50 women and 50 men participated in this study. About 24 samples $(24 \%)$ were positive for influenza virus, while 5 samples $(5 \%)$ were contained the parainfluenza virus. There was no co-infection between influenza and parainfluenza viruses.

Demographic information about affected people is listed in the following tables. The age range of the patients was between 42 and 97 years, with the mean age of 39 years. According to obtained results and based on the Chi-square test, there was a significant relationship between sex and the detection of influenza virus $(\mathrm{P}<0.05)$, while no significant correlation was detected between personality characteristics (sex and age) and the infection with parainfluenza viruses $(\mathrm{P}>0.05)$ (Table 3 ).

The various clinical symptoms were studied in patients, and a significant relationship was found between some symptoms like pain, fever, and joint pain with the presence of the influenza virus in the clinical samples
$(\mathrm{P}<0.05)$. However, we did not detect this issue about other symptoms. Also, we detected a significant correlation between the presence of some symptoms such as fever and runny nose and the positive results for parainfluenza $(\mathrm{P}<0.05)$. Table 4 presents information about clinical symptoms in patients infected with two investigated viruses.

\section{Underlying medical conditions}

There was a significant relationship between the presence of some underlying conditions and the positive results of the influenza virus, while no correlation was seen concerning the parainfluenza viruses (Table 5).

\section{Complications in Influenza and parainfluenza in- fected patients}

Out of all patients with influenza, 7 (29.1\%) showed bacterial pneumonia after a viral infection, while 2 (40\%) of parainfluenza infected patients exhibited this complication. Also, $2(8.3 \%)$ and $1(20 \%)$ patient(s) af-

Table 5. Prevalence of underlying diseases in patients infected with human parainfluenza and influenza viruses

\begin{tabular}{|c|c|c|c|c|c|c|c|}
\hline \multirow[b]{2}{*}{$\begin{array}{l}\text { Underlying Diseases in } \\
\text { Patients }\end{array}$} & \multicolumn{7}{|c|}{ No. (\%) of Patients } \\
\hline & 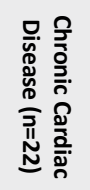 & 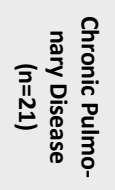 & 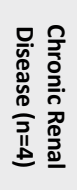 & 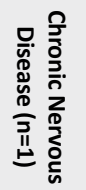 & 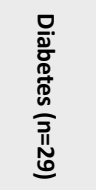 & 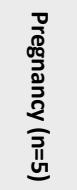 & 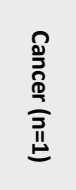 \\
\hline Influenza & $9(40.9)$ & $5(23.8)$ & $1(25)$ & - & $7(24.1)$ & $4(80)$ & $1(100)$ \\
\hline$P$ & 0.048 & 0.614 & 0.673 & 0.760 & 0.586 & 0.011 & 0.240 \\
\hline Parainfluenza & $1(4.5)$ & - & - & - & - & - & - \\
\hline$P$ & 0.697 & 0.360 & 0.812 & 0.950 & 0.318 & 0.770 & 0.491 \\
\hline
\end{tabular}


fected by influenza and parainfluenza viruses suffered from bronchiolitis. On the other hand, while all parainfluenza positive patients cured after disease, 3 (12.5\%) patients with influenza signs died after infection.

\section{Discussion}

Parainfluenza virus infection is prevalent among children causing $40 \%$ of lower respiratory tract infections and $20 \%$ of all respiratory diseases in hospitalized children [4]. The most infections caused by this virus in adults are mild upper respiratory tract and severe lower respiratory infections such as pneumonia [20, 21]. However, the influenza virus is widespread in all age groups, resulting in 300000-500000 deaths worldwide annually due to respiratory tract obstruction along with destroying alveolar and respiratory epithelium [13].

According to the obtained results, influenza was more prevalent $(24 \%)$ than parainfluenza $(5 \%)$ infection in this area of Iran. These rates in Greece were reported as $11 \%$ and $7.5 \%$ for influenza and parainfluenza infections, respectively [22]. Also, another study conducted in Georgia in 2004 showed the prevalence rates of $3 \%$ and $7 \%$ of influenza and parainfluenza infections, respectively [21]. According to a study carried out in Iran (Zahedan City), the prevalence of influenza virus was $81.7 \%$, while no patients infected by parainfluenza viruses were detected [23]. The higher prevalence of influenza virus in this study may be due to the climate difference and living conditions in the southern provinces of Iran.

Among 843 pediatric patients with influenza-like symptoms and respiratory infections in India from 2009 to 2011 , rhinovirus was the most detected virus $(17.2 \%)$ followed by H1N1pdm09 (8.54\%) and parainfluenza virus-3 $(5.8 \%)$, and the prevalence of parainfluenza virus was almost equal to the present study [24]. On the other hand, the data published about 89 registered nasopharyngeal swabs collected from patients with pediatric cancers along with influenza-like illnesses in Lebanon in 2019 revealed that $26 \%$ of the patients were infected by both influenza virus and parainfluenza virus [25], while the sampling method in mentioned research was different with the present study. However, some studies carried out in other regions show that the prevalence of parainfluenza viruses is more than the influenza virus.

For instance, the prevalence rates of parainfluenza and influenza viruses in Brazil were $30 \%$ and $21 \%$, respectively [26]. Moreover, in a study conducted in Korea between 2 groups of patients with severe and stable con- ditions, the parainfluenza virus was the most common virus $(16.8 \%)$ detected [27].

The results of our study showed no significant relationship between the age and sex of the patients and the presence of parainfluenza virus, while there was a significant relationship between sex and cases with influenza virus. This relationship may be because children, who are at higher risk for infection with parainfluenza viruses, have the lowest probability of hospital admission, especially in ICU, intubation, or being prescribed antibiotics. While most studies indicated that this virus is a common pathogen in children and babies, in a study conducted in London, parainfluenza viruses were detected among adults (25-80 years old) as well as the children under 5 years old [28].

Clinical features of the patients in the present study were different among parainfluenza types. Previous studies on HPIV-4 exhibited various conclusions about its clinical relevance [29]. While some reports suggest that HPIV-4 has minimal clinical impacts, others find its associations with significant illnesses [30, 31]. Several studies show the relationship between the clinical symptoms and the presence of parainfluenza viruses. Wen-Kuan Liu et al. in China found a significant correlation between HPIV infection and the emergence of a broad spectrum of symptoms, abnormal pulmonary breathing sounds, dyspnea, pneumonia, and diarrhea in the patients [32]

Also, a study carried out by Alma et al. in the Netherlands showed a significant relationship between bronchitis, rhinitis, pharyngitis, and croup and the presence of parainfluenza infections [33]. Moreover, the most common symptoms of parainfluenza infected patients observed in another study conducted in Hong Kong were fever, cough, sore throat, and vomiting [31]. However, we detected a significant relationship between the signs of chill and rhinorrhea and the positive results of parainfluenza in patients.

On the other hand, we found a significant correlation between the emergence of symptoms such as pain, fatigue, chill, joint pain, and the presence of influenza virus in clinical samples of the patients $(\mathrm{P}<0.05)$. However, there was a significant correlation between the presence of influenza virus and observation of myalgia, headache, gastrointestinal symptoms, and dyspnea in a study conducted in Zahedan City, Southwest of Iran [23]. According to a study by Arnold Monto et al. in Michigan, the most commonly described symptoms were weakness (94\%), myalgia (94\%), cough (93\%), 
nasal congestion (91\%), and feeling of fever or chills in influenza-positive patients [34].

Also, we found that 3 patients $(12.5 \%)$ with influenzapositive results died after infection; 2 were more than 75 years old, and 1 was a child younger than 3 years. The child had cancer and a history of chemotherapy. This shows that the presence of underlying diseases can result in exacerbated diseases caused by influenza and parainfluenza viruses in immunosuppressed patients. We detected a relationship between some of these situations, such as chronic cardiac diseases, pregnancy, taking aspirin, and the presence of severe influenza infection, resulting in admission to the hospital and receiving oxygen. On the other hand, we found no statistically significant differences between the presence of parainfluenza viruses and underlying diseases. However, a study by Rogério Pecchini et al. in Brazil shows a significant relationship between the positive parainfluenza virus infections and the presence of premature birth, congenital cardiopathy, gastroesophageal reflux, along with the family history of atopy and smoking [35].

\section{Conclusions}

The results of this study revealed the higher prevalence of influenza virus in our local area. The effects of influenza and parainfluenza in hospitalized patients, particularly in children, are very noticeable, suggesting the necessity of continuous surveillance, infection control, and annual vaccination for influenza virus, especially in children. The surveillance studies should be performed in different areas to invent plans for the prevention and treatment of influenza. Using diagnostic tests such as reverse-transcription PCR and real-time PCR can confirm respiratory viruses. We can use the PCR method to increase the chance of respiratory viruses' detection in patients admitted to the hospitals with respiratory symptoms resulting in more accurate diagnosis and saving time. This knowledge can help physicians for ideal patient management leading to better infection control in communities and hospitals.

\section{Ethical Considerations}

\section{Compliance with ethical guidelines}

This study was based on clinical specimens from suspected patients with influenza who referred to Mazandaran Province medical centers, Moreover, sample collection was carried out with the consent of the patients, and in accordance with the principles of health and standards of the Ethics Committee and the ethical (Code IR.MAZUMS.REC.1397.3012).

\section{Funding}

This research was financially supported by Mazandaran University of Medical Sciences, Sari, Iran, with Grant number 3012 .

\section{Authors contribution's}

All authors contributed in preparing this article.

\section{Conflict of interest}

The authors declare no conflict of interest.

\section{References}

[1] Couch RB. Orthomyxoviruses. In: Baron S, editor. Medical Microbiology. 4th ed. Galveston (TX): University of Texas Medical Branch at Galveston; 1996. [PMID]

[2] Counihan ME, Shay DK, Holman RC, Lowther SA, Anderson LJ. Human parainfluenza virus-associated hospitalizations among children less than five years of age in the United States. Pediatr Infect Dis J. 2001; 20(7):646-53. [DOI:10.1097/00006454-200107000-00003] [PMID]

[3] Watanabe N, Kawano M, Tsurudome M, Kusagawa S, Nishio M, Komada $\mathrm{H}$, et al. Identification of the sequences responsible for nuclear targeting of the $\mathrm{V}$ protein of human parainfluenza virus type 2. J Gen Virol. 1996; 77(Pt 2):327-38. [DOI:10.1099/0022-1317-77-2-327] [PMID]

[4] Aguilar JC, Perez-Brena MP, Garcia ML, Cruz N, Erdman DD, Echevarria JE. Detection and identification of human parainfluenza viruses 1,2,3, and 4 in clinical samples of pediatric patients by multiplex reverse transcription-PCR. J Clin Microbiol. 2000; 38(3):1191-5. [DOI:10.1128/JCM.38.3.11911195.2000] [PMID] [PMCID]

[5] Wendt CH, Weisdorf DJ, Jordan MC, Balfour HH Jr, Hertz MI. Parainfluenza virus respiratory infection after bone marrow transplantation. N Engl J Med. 1992; 326(14):921-6. [DOI:10.1056/NEJM199204023261404] [PMID]

[6] Fan J, Henrickson KJ, Savatski LL. Rapid simultaneous diagnosis of infections with respiratory syncytial viruses A and $B$, influenza viruses $A$ and $B$, and human parainfluenza virus types 1,2 , and 3 by multiplex quantitative reverse transcription-polymerase chain reaction-enzyme hybridization assay (Hexaplex). Clin Infect Dis. 1998; 26(6):1397-402. [DOI:10.1086/516357] [PMID]

[7] Meissner HC, Murray SA, Kiernan MA, Snydman DR, McIntosh K. A simultaneous outbreak of respiratory syncytial virus and parainfluenza virus type 3 in a newborn nursery. J Pediatr. 1984; 104(5):680-4. [DOI:10.1016/S00223476(84)80943-9] 
[8] Echevarria JE, Erdman DD, Swierkosz EM, Holloway BP, Anderson LJ. Simultaneous detection and identification of human parainfluenza viruses 1, 2, and 3 from clinical samples by multiplex PCR. J Clin Microbiol. 1998; 36(5):1388-91. [DOI:10.1128/JCM.36.5.1388-1391.1998] [PMID] [PMCID]

[9] Downham MA, McQuillin J, Gardner PS. Diagnosis and clinical significance of parainfluenza virus infections in children. Arch Dis Child. 1974; 49(1):8-15. [DOI:10.1136/adc.49.1.8] [PMID] [PMCID]

[10] Luo M. Influenza virus entry. Adv Exp Med Biol. 2012; 726:201-21. [DOI:10.1007/978-1-4614-0980-9_9] [PMID]

[11] Bouvier NM, Palese P. The biology of influenza viruses. Vaccine. 2008; 26(Suppl. 4):D49-53. [DOI:10.1016/j.vaccine.2008.07.039] [PMID] [PMCID]

[12] Potter CW. A history of influenza. J Appl Microbiol. 2001; 91(4):572-9. [DOI:10.1046/j.1365-2672.2001.01492.x] [PMID]

[13] World Health Organization. WHO manual on animal influenza diagnosis and surveillance [Internet]. 2002 [Updated 2002 May 5]. Available from: https://apps.who.int/iris/ handle/10665/68026

[14] Vemula SV, Zhao J, Liu J, Wang X, Biswas S, Hewlett I. Current approaches for diagnosis of influenza virus infections in humans. Viruses. 2016; 8(4):96. [DOI:10.3390/v8040096] [PMID] [PMCID]

[15] Atmar RL, Baxter BD, Dominguez EA, Taber LH. Comparison of reverse transcription-PCR with tissue culture and other rapid diagnostic assays for detection of type A influenza virus. J Clin Microbiol. 1996; 34(10):2604-6. [DOI:10.1128/ JCM.34.10.2604-2606.1996] [PMID] [PMCID]

[16] Peteranderl C, Herold S, Schmoldt C. Human influenza virus infections. Semin Respir Crit Care Med. 2016; 37(4):487500. [DOI:10.1055/s-0036-1584801] [PMID]

[17] Kim DK, Poudel B. Tools to detect influenza virus. Yonsei Med J. 2013; 54(3):560-6. [DOI:10.3349/ymj.2013.54.3.560] [PMID] [PMCID]

[18] Taubenberger JK, Morens DM. The pathology of influenza virus infections. Annu Rev Pathol. 2008; 3:499-522. [DOI:10.1146/annurev.pathmechdis.3.121806.154316] [PMID] [PMCID]

[19] Ngaosuwankul N, Noisumdaeng P, Komolsiri P, Pooruk $\mathrm{P}$, Chokephaibulkit K, Chotpitayasunondh T, et al. Influenza A viral loads in respiratory samples collected from patients infected with pandemic H1N1, seasonal H1N1 and H3N2 viruses. Virol J. 2010; 7:75. [DOI:10.1186/1743422X-7-75] [PMID] [PMCID]

[20] Hsieh YJ, Chin H, Chiu NC, Huang FY. Hospitalized pediatric parainfluenza virus infections in a medical center. J Microbiol Immunol Infect. 2010; 43(5):360-5. [DOI: 10.1016/ S1684-1182(10)60057-6] [PMID]

[21] Iwane MK, Edwards KM, Szilagyi PG, Walker FJ, Griffin MR, Weinberg GA, et al. Population-based surveillance for hospitalizations associated with respiratory syncytial virus, influenza virus, and parainfluenza viruses among young children. Pediatrics. 2004; 113(6):1758-64. [DOI:10.1542/ peds.113.6.1758] [PMID]
[22] Dimopoulos G, Lerikou M, Tsiodras S, Chranioti A, Perros E, Anagnostopoulou U, et al. Viral epidemiology of acute exacerbations of chronic obstructive pulmonary disease. Pulm Pharmacol Ther. 2012; 25(1):12-8. [DOI:10.1016/j. pupt.2011.08.004] [PMID]

[23] Mood FS, Tabatabaei SM, Sharifi-Mood B, Khalili T, Arbabi N, Metanat M, et al. The Prevalence of Respiratory Viruses Among Patients with Influenza-Like Illness in Zahedan, Southeastern Iran. Arch Clin Infect Dis. 2016; 14(3):5. [DOI:10.5812/archcid.77089]

[24] Choudhary ML, Anand SP, Heydari M, Rane G, Potdar VA, Chadha MS, et al. Development of a multiplex one step RT-PCR that detects eighteen respiratory viruses in clinical specimens and comparison with real time RT-PCR. J Virol Methods. 2013; 189(1):15-9. [DOI:10.1016/j.jviromet.2012.12.017] [PMID]

[25] Soudani N, Caniza MA, Assaf-Casals A, Shaker R, Lteif M, $\mathrm{Su} Y$, et al. Prevalence and characteristics of acute respiratory virus infections in pediatric cancer patients. J Med Virol. 2019; 91(7):1191-201. [DOI:10.1002/jmv.25432] [PMID]

[26] Raboni SM, Moura FE, Caetano BC, Avanzi VM, Pereira LA, Nogueira MB, et al. Global Influenza Hospital-based Surveillance Network (GIHSN): Results of surveillance of influenza and other respiratory viruses in hospitalised patients in Brazil, 2015. BMJ Open. 2018; 8(2):e017603. [DOI:10.1136/bmjopen-2017-017603] [PMID] [PMCID]

[27] Seo KH, Bae DJ, Kim JN, Lee HS, Kim YH, Park JS, et al. Prevalence of respiratory viral infections in Korean adult asthmatics with acute exacerbations: Comparison with those with stable state. Allergy Asthma Immunol Res. 2017 9(6):491-8. [DOI:10.4168/aair.2017.9.6.491] [PMID] [PMCID]

[28] Gardner SD. The isolation of parainfluenza 4 subtypes A and $\mathrm{B}$ in England and serological studies of their prevalence. J Hyg (Lond). 1969; 67(3):545-50. [DOI:10.1017/ S002217240004198X] [PMID] [PMCID]

[29] Lau SK, Li KS, Chau KY, So LY, Lee RA, Lau Yl, et al Clinical and molecular epidemiology of human parainfluenza virus 4 infections in Hong Kong: Subtype 4B as common as subtype 4A. J Clin Microbiol. 2009; 47(5):1549-52. [DOI:10.1128/JCM.00047-09] [PMID] [PMCID]

[30] Frost HM, Robinson CC, Dominguez SR. Epidemiology and clinical presentation of parainfluenza type 4 in children: A 3-year comparative study to parainfluenza types 1-3. J Infect Dis. 2014; 209(5):695-702. [DOI:10.1093/infdis/jit552] [PMID] [PMCID]

[31] Lau SK, To WK, Tse PW, Chan AK, Woo PC, Tsoi HW, et al. Human parainfluenza virus 4 outbreak and the role of diagnostic tests. J Clin Microbiol. 2005; 43(9):4515-21. [DOI:10.1128/JCM.43.9.4515-4521.2005] [PMID] [PMCID]

[32] Liu WK, Liu Q, Chen DH, Liang HX, Chen XK, Huang WB, et al. Epidemiology and clinical presentation of the four human parainfluenza virus types. BMC Infect Dis. 2013; 13:28. [DOI:10.1186/1471-2334-13-28] [PMID] [PMCID]

[33] van de Pol AC, van Loon AM, Wolfs TF, Jansen NJ, Nijhuis M, Breteler EK, et al. Increased detection of respiratory syncytial virus, influenza viruses, parainfluenza viruses, and adenoviruses with real-time PCR in samples from patients with respiratory symptoms. J Clin Microbiol. 2007; 45(7):2260-2. [DOI:10.1128/JCM.00848-07] [PMID] [PMCID] 
[34] Monto AS, Gravenstein S, Elliott M, Colopy M, Schweinle J. Clinical signs and symptoms predicting influenza infection. Arch Intern Med. 2000; 160(21):3243-7. [DOI:10.1001/ archinte.160.21.3243] [PMID]

[35] Pecchini R, Berezin EN, Souza MC, Vaz-de-Lima Lde A, Sato N, Salgado M, et al. Parainfluenza virus as a cause of acute respiratory infection in hospitalized children. Braz J Infect Dis. 2015; 19(4):358-62. [DOI:10.1016/j.bjid.2015.03.002] [PMID] 
This Page Intentionally Left Blank 